\title{
Analysis of X-Ray Photoelectron Spectra of Silicon-Based Polymers by deMon Density-Functional Calculations Using Model Molecules
}

\author{
Shigeki KuroKi, ${ }^{\dagger}$ Kazunaka Endo, ${ }^{*}$ Shigehiro MaEda, ${ }^{* *}$ \\ Delano P. CHONG, ${ }^{* * *}$ and Patrick DufFY ${ }^{* * *}$ \\ Advanced Polymer Laboratory, Japan High Polymer Center, \\ 2-1-6 Sengen, Tsukuba, Ibaraki 305, Japan \\ * Department of Chemistry, Faculty of Science, Kanazawa University, \\ Kakuma-machi, Kanazawa 920-11, Japan \\ ** Tsukuba Research Laboratory, Mitsubishi Paper Mills, Ltd., \\ 46 Wadai, Tsukuba 300-42, Japan \\ *** Departmentof Chemistry, 2036 Main Mall, Univesity of British Columbia, \\ Vancouver, B.C., Canada V6T 1Z1
}

(Received September 9, 1997)

\begin{abstract}
The X-ray photoelectron spectra (XPS) of seven silicon-based polymers[ $\left(-\mathrm{Si}\left(\mathrm{CH}_{3}\right)_{2}-\right)_{n}$ (PDMS), $\left(-\mathrm{Si}\left(\mathrm{C}_{6} \mathrm{H}_{5}\right)\left(\mathrm{CH}_{3}\right)-\right)_{n}$ (PMPS), (- $\left.\mathrm{Si}\left(n-\mathrm{C}_{6} \mathrm{H}_{13}\right)_{2}-\right)_{n}$ (PDHS), (-Si( $\left.\left(\mathrm{CH}_{3}\right)_{2}-\mathrm{O}-\right)_{n}(\mathrm{PDMSO}),\left(-\mathrm{Si}_{6}\left(\mathrm{C}_{6} \mathrm{H}_{5}\right)\left(\mathrm{CH}_{3}\right)-\mathrm{O}-\right)_{n}$ (PMPSO), $\left(-\mathrm{Si}\left(\mathrm{CH}_{3}\right)\left(\mathrm{C}_{6} \mathrm{H}_{5}\right)-\mathrm{CH}_{2}-\right)_{n}$ (PMPSM), and $\left(-\mathrm{Si}\left(\mathrm{C}_{6} \mathrm{H}_{5}\right)_{2}-\mathrm{CH}_{2}-\right)_{n}$ (PDPSM)] in XPS were analyzed by deMon density-functional calculations using model molecules. Calculated $\mathrm{Al}-\mathrm{K}_{\alpha}$ valence photoelectron spectra were obtained using Gaussian lineshape functions of an approximate linewidth $\left(0.10 I_{\mathrm{k}}\right): I_{\mathrm{k}}=I_{\mathrm{k}}^{\prime}-W D$, as in previous works. The vertical ionization potential $I_{\mathrm{k}}^{\prime}$ was calculated by restricted diffuse ionization (rDI) model. The theoretical spectra showed good agreement with the observed spectra of the polymers between $0-40 \mathrm{eV}$. The core-electron binding energies (CEBEs) of C1s, Ols and $\mathrm{Si} 2 \mathrm{p}$ of the model molecules were calculated by unrestricted generalized-state (uGTS) models. The difference between calculated and the observed CEBEs for $\mathrm{C} 1 \mathrm{~s}$ reflected $W D$ s of the polymers.

KEY WORDS Silicon-Based Polymer / X-Ray Photoelectron Spectra / Electronic State / DensityFunctional Calculation / Fermi Level /
\end{abstract}

Silicon-based polymers are of the increasing interest owing to latent technical applications as ceramics precursors, ${ }^{1}$ photoresists, ${ }^{2}$ initiators for radical polymerization, ${ }^{3}$ photoconductors, ${ }^{4}$ and materials for nonlinear optics, ${ }^{5}$ since the discovery of a soluble polysilane, in $1980 .^{6}$ Some basic physico-chemical studies have been performed $\mathrm{UV},{ }^{7}$ GCP, ${ }^{8}$ light-scattering, ${ }^{9}$ and $\mathrm{NMR}$ analyses ${ }^{10}$ of the polymers. They provided information on electronic delocalization, determination of molecular weight, and structural analytical data of the polymerchains. We investigate here the nature of chemical bonds of silicon-based polymers, although there is an article ${ }^{11}$ which examines the electronic states of polysilane and polydimethylsilane using X-ray and UV photoelectron spectra (XPS) of the polymers.

Previous studies ${ }^{12-14}$ showed better assignment of the valence XPS of polymers involving carbon, nitrogen, oxygen and fluorine using the semiempirical hydrogenicatoms-in-molecule, version 3 (HAM/3) MO method. ${ }^{15-18}$ The results can be directly compared with experiment, because the idea of "transition-state" 19 rather than Koopmans' theorem is used to predict vertical ionization potentials (VIPs). In recent studies of density-functional theory (DFT) using the deMon DFT program ${ }^{20}$ which uses the idea of transition state, Chong and coworkers $^{21-25}$ offered the method of calculating accurate VIPs and core-electron binding energies (CEBEs) of small molecules.

In our recent paper ${ }^{26}$ on the density-functional theory DFT by energy shift $W D$ to account for solid-state effects, we calculated accurate CEBEs of eight polymers involving $\mathrm{C}, \mathrm{N}, \mathrm{O}, \mathrm{F}, \mathrm{S}$, and $\mathrm{Cl}$ atoms and simulated the valence XPS. The present paper follows the same procedures of DFT with the energy shift $W D$ to simulate the valence XPS of seven silicon-based polymers $\left[\left(-\mathrm{Si}\left(\mathrm{CH}_{3}\right)_{2}-\right)_{n}\right.$ (PDMS), $\left(-\mathrm{Si}\left(\mathrm{C}_{6} \mathrm{H}_{5}\right)\left(\mathrm{CH}_{3}\right)-\right)_{n}$ (PMPS), $\left(-\mathrm{Si}\left(n-\mathrm{C}_{6} \mathrm{H}_{13}\right)_{2}-\right)_{n}$ (PDHS), $\left(-\mathrm{Si}\left(\mathrm{CH}_{3}\right)_{2}-\mathrm{O}-\right)_{n}$ (PDMSO), $\left(-\mathrm{Si}\left(\mathrm{C}_{6} \mathrm{H}_{5}\right)\left(\mathrm{CH}_{3}\right)-\mathrm{O}-\right)_{n}$ (PMPSO), $\left(-\mathrm{Si}\left(\mathrm{CH}_{3}\right)\left(\mathrm{C}_{6} \mathrm{H}_{5}\right)-\right.$ $\left.\mathrm{CH}_{2}-\right)_{n}(\mathrm{PMPSM})$ and $\left(-\mathrm{Si}\left(\mathrm{C}_{6} \mathrm{H}_{5}\right)_{2}-\mathrm{CH}_{2}-\right)_{n}$ (PDPSM)], and to calculate CEBEs. The simulation of the valence spectra was performed on the model molecules with polarized valence double-zeta (DZVP) using standard convolution by a Gaussian line shape and using the Gelius model ${ }^{27}$ for molecular photoionization cross sections. The line width of a peak of ionization energy $I_{\mathrm{k}}$ was taken to be $0.10 I_{\mathrm{k}}$ (proportinal to the ionization energy) as in previous studies. ${ }^{12-14} \mathrm{CEBEs}$ of $\mathrm{C} 1 \mathrm{~s}, \mathrm{O} 1 \mathrm{~s}$, and $\mathrm{Si} 2 \mathrm{p}$ of the model molecules were calculated using the deMon DFT program with scaled polarized valence triple-zeta (scaled-pVTZ). Our results showed good correspondence with experimental data.

\section{THEORETICAL BACKGROUND}

As indicated in previous works, ${ }^{12-14}$ we used the relation between calculations for a single molecules and experiments on a solid polymer: $I_{\mathrm{k}}\left(E_{\mathrm{F}}\right)=I_{\mathrm{k}}^{\prime}-W D$, where $I_{\mathrm{k}}\left(E_{\mathrm{F}}\right)$ is the ionization energy relative to the Fermi level. $I_{\mathrm{k}}^{\prime}$ and $W D$ denote computed VIPs (or CEBEs) and the sum of the work function of the sample and other energy effects, respectively.

In the generalized transition-state (GTS) method,

† Present Address: Dept. of Polymer Chemistry, Tokyo Institute of Technology, 2-12-1 Ookayama, Meguro-ku, Tokyo 152, Japan. 
Williams et al. ${ }^{28}$ proposed the extension of Slater's transition-state method ${ }^{19}$ and approximated the endothermicity $\Delta E=E(1)-E(0)$ by

$$
\Delta E=[F(0)+3 F(2 / 3)] / 4,
$$

where $F(x)=\partial E(x) / \partial x$, and $x$ is assumed to be a continuous variable, with $E(0)$ and $E(1)$ denoting the energies of the initial and final states, respectively. For example, for the ionization of an electron from molecular orbital (MO) $\phi_{\mathrm{k}}, x$ represents the fraction of electron removed, and, according to the Janak theorem, ${ }^{29} F(x)$ is the negative orbital energy $\varepsilon_{\mathrm{k}}(x)$. This procedure is applied in the following way. In the unrestricted generalized transition-state (uGTS) method, we remove $2 / 3$ alpha electron from MO $\phi_{\mathrm{k}}$ of interest.

\section{Valence Region of XPS of Polymers}

For the VIPs of the valence regions, we use the so-called diffuse ionization (DI) model which Asbrink et al. ${ }^{16}$ proposed in the HAM 3 method. In the rDI model, half an electron is removed evenly from the valence MOs and the negative orbital energies correspond to calculated VIPs. This allows us to obtain all the valence VIPs in a single calculation. The $\mathrm{C}_{2} \mathrm{H}_{2}$ molecule, with five valence MOs and ten valence electrons can be used as an example. For the rDI model, each valence $\mathrm{MO}$ of $\mathrm{C}_{2} \mathrm{H}_{2}$ has 0.95 alpha and 0.95 beta electrons.

\section{Core-Electron Binding Energies}

Following Chong, ${ }^{24,25}$ we used the GTS model to compute CEBEs and added relativistic correction $\left(C_{\text {rel }}\right)$ for $C$ to $F$ using $C_{\text {rel }}=K I_{\mathrm{nr}}{ }^{\mathrm{N}}$ where $K=2.198 \times 10^{-7}$, $N=2.178$, and $I_{\mathrm{nr}}$ is the nonrelativistic CEBE. Since the corresponding $C_{\text {rel }}$ expression has not been determined for $\mathrm{S}$ and $\mathrm{Cl}$, we did not add $C_{\text {rel }}$ for $\mathrm{Si}$ atom in the present study.

\section{CALCULATIONS}

\section{MO Calculations}

In the deMon program, we used the maximum number of primitive bases in all contractions combined, contractions, orbitals, and atoms as 3600, 900, 255, and 45 , respectively. We, thus, considered the model $n$-mer $(n=1,2,3)$ due to the maximum numbers.

Valence XPS. We calculated the model molecules $\left[\mathrm{H}\left(\mathrm{Si}\left(\mathrm{CH}_{3}\right)_{2}\right)_{3} \mathrm{H}, \mathrm{H}\left(\mathrm{Si}\left(\mathrm{C}_{6} \mathrm{H}_{5}\right)\left(\mathrm{CH}_{3}\right)\right) \mathrm{H}, \mathrm{H}(\mathrm{Si}(n-\right.$ $\left.\left.\mathrm{C}_{6} \mathrm{H}_{13}\right)_{2}\right) \mathrm{H}, \mathrm{H}\left(\mathrm{Si}\left(\mathrm{CH}_{3}\right)_{2} \mathrm{O}\right)_{2} \mathrm{H}, \mathrm{H}\left(\mathrm{Si}\left(\mathrm{C}_{6} \mathrm{H}_{5}\right)\left(\mathrm{CH}_{3}\right) \mathrm{O}\right) \mathrm{H}$, $\mathrm{H}\left(\mathrm{Si}\left(\mathrm{CH}_{3}\right)\left(\mathrm{C}_{6} \mathrm{H}_{5}\right) \mathrm{CH}_{2}\right) \mathrm{H}$, and $\left.\mathrm{H}\left(\mathrm{Si}\left(\mathrm{C}_{6} \mathrm{H}_{5}\right)_{2} \mathrm{CH}_{2}\right) \mathrm{H}\right]$ using the density-functional deMon program ${ }^{20}$ to simulate the valence XPS of the polymers. For the geometry of the molecules, we used the optimized cartesian coordinates from the semiempirical AM1 (version 6.0) method. ${ }^{30}$

DeMon calculations were performed with the exchange-correlation potential labeled as B88/P86, made from Becke's 1988 exchange functional ${ }^{31}$ and Perdew's 1986 correlation functional. ${ }^{32}$ In the program, we used a nonrandom grid and polarized valence double-zeta (DZVP) basis of $\left(621 / 41 / 1^{*}\right)$ for $\mathrm{C}$ and $\mathrm{O}$, (41) for $\mathrm{H}$ and $\left(6321 / 521 / 1^{*}\right)$ for $\mathrm{Si}$ with auxiliary fitting functions labeled $(4,4 ; 4,4)$ for $\mathrm{C}$ and $\mathrm{O},(3,1 ; 3,1)$ for $\mathrm{H}$ and $(5,4 ; 5,4)$ for $\mathrm{Si}$.
Table I. Relative photoionization cross-sections (PICS) of atomic orbitals for $\mathrm{H}, \mathrm{C}, \mathrm{O}, \mathrm{Si}, \mathrm{S}$, and $\mathrm{Cl}$ atoms (relative to $\mathrm{C} 2 \mathrm{~s}$ )

\begin{tabular}{ccc}
\hline Atomic & Orbital & $\mathrm{Al}-K_{\alpha}\left(\mathrm{Yeh}^{42}\right)$ \\
\hline $\mathrm{H}$ & $1 \mathrm{~s}$ & 0.0041 \\
$\mathrm{C}$ & $2 \mathrm{~s}$ & 1.0000 \\
& $2 \mathrm{p}$ & 0.0323 \\
$\mathrm{O}$ & $2 \mathrm{~s}$ & 2.8602 \\
& $2 \mathrm{p}$ & 0.3910 \\
$\mathrm{Si}$ & $3 \mathrm{~s}$ & 1.5759 \\
& $3 \mathrm{p}$ & 0.2887 \\
\hline
\end{tabular}

Core-Electron Binding Energies.To calculate MOs of the model molecules (in Table VII) in the initial state, we used the consistent-correlation polarized valence triple-zeta (cc-pVTZ).

We calculated the CEBEs of the model molecules (in Table VII) using the B88/B86 functional and the uGTS model with the scaled polarized valence triple-zeta(scaled-pVTZ) basis for $\mathrm{C}, \mathrm{H}, \mathrm{O}$, and $\mathrm{Si}$. In the CEBE calculations with scaled pVTZ, we used the new scaling factors for the Gaussian-type orbitals (GTO)s of Si atoms with the factors for the second-period atoms as given by Chong and co-workers. ${ }^{25}$

\section{Spectral Simulation}

To simulate the valence XPS of the polymers theoretically, we constructed from a superposition of peaks centered on the VIPs, $I_{\mathrm{k}}$. As was done in previous work, ${ }^{12-14}$ each peak was represented by a Gaussian curve. The intensity was estimated from the relative photoionization cross section for $\mathrm{Al}-K_{\alpha}$ radiation using the Gelius intensity model. ${ }^{27}$ For the relative atomic photoionization cross-sectin, we used the theoretical values from Yeh (Table I). ${ }^{33}$ In the case of the linewidth $(W H(k))$, we used $W H(k)=0.10 I_{\mathrm{k}}$ for the models, as in previous work. ${ }^{12-14}$

\section{EXPERIMENTAL}

The experimental photoelectron spectra of 10 polymers were obtained on a PHI 5400 MC ESCA spectrometer, using monochromatized $\mathrm{Al}-K_{\alpha}$ radiation. The spectrometer was operated at $600 \mathrm{~W}, 15 \mathrm{kV}$, and $40 \mathrm{~mA}$. Photon energy was $1486.6 \mathrm{eV}$. A pass energy of $35.75 \mathrm{eV}$ was used for high-resolution scans in a valence-band analysis ( $50 \mathrm{eV}$ of range). The angle between the $\mathrm{X}$-ray source and analyzer was fixed at $45^{\circ}$. Spot size was $3 \times 1 \mathrm{~mm}$.

Dispersion compensation yielded an instrumental resolution of $0.5 \mathrm{eV}$ with full width at half-maximum on the Ag3d line of silver. Multiple-scan averaging on a multichannel analyzer was used for the valence-band region, although a very low photoelectron emission cross section was observed in this range.

We used five silicon-based polymers PDMS, PMPS, PDHS, PMPSM, and PDPSM synthesized at the Advanced Polymer Laboratory of the Japan High Polymer Center. For polysiloxanes, we used commerciallyavailable PDMSO (Aldrich Chemical Co., Inc.), PMPSO (Aldrich Chemical Co., Inc.). The samples except for PMPSM and PDPSM were prepared by cast-coating 


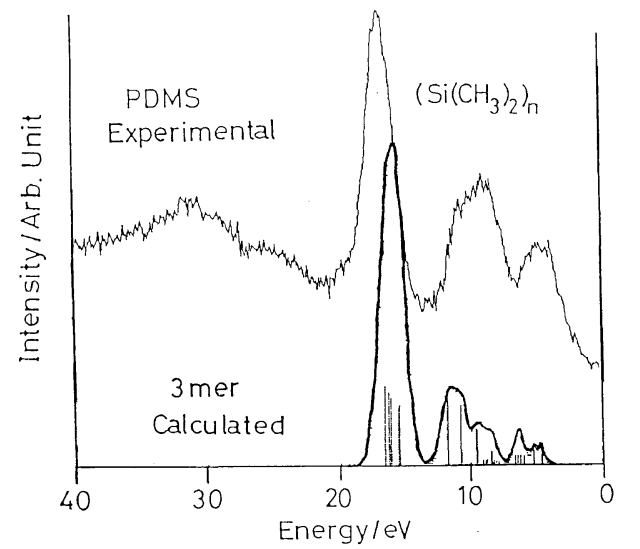

Figure 1. Valence XPS of PDMS with the simulated spectra of the trimer model molecule as calculated using deMon DFT.

the polymer solution on an aluminium plate, with chloroform. For PMPSM and PDPSM, we used the film and pressed disc, respectively. The film was estimated to be a few tens of micrometers thick. Gold of $20 \mathrm{~A}$ thick was deposited on the films (or disc) of the polymer samples using an ion sputter unit (Hitachi E1030) for scanning electron microscope.

A low-energy electron flood gun was used to avoid any charging effect on the surface of the sample. We used the Au4f core level of the gold decoration film(or disc) as a calibration reference. The $\mathrm{Cls}$ line positions of $\mathrm{CH}_{3}$, $\mathrm{CH}_{2}$, and $\mathrm{C}_{6} \mathrm{H}_{5}$ groups on the $\mathrm{Si}$-based polymer films could be fixed in the range of $283.2-284.6 \mathrm{eV}$ for the polymer, as indicated in Table VII.

\section{RESULTS AND DISCUSSION}

\section{Valence XPS of Silicon-Based Polymers}

Present study used the rDI model with the deMon program for the simulation of valence spectra of siliconbased polymers, since we were only able to calculate the valence XPS of polymers involving $\mathrm{C}, \mathrm{N}, \mathrm{O}$ and $\mathrm{F}$ atoms except for $-\mathrm{CN}$ group with the HAM $/ 3$ method.

PDMS, PMPS, and PDHS polymers. Figures 1, 2a, and $2 \mathrm{~b}$ indicate the simulated spectra of PDMS, PMPS, and PDHS using the model molecules with observed spectra. In the figures, there exist characteristic spectra, in the range of $12-22 \mathrm{eV}$, due to the difference between the pendant groups $\left(-\mathrm{CH}_{3},-\mathrm{C}_{6} \mathrm{H}_{5}\right.$, and $\left.-\mathrm{C}_{6} \mathrm{H}_{13}\right)$.

The intense peak of PDMS results from the s-sigma (C2s-Si3s) bonding orbitals, and the shoulder peak between 10 and $12.5 \mathrm{eV}$ owes to the p-sigma(Si3s-Si3p) bonding orbitals. In the case of PMPS in Figure $2 \mathrm{a}$, three peaks $(19.5,17.0$, and $13.0 \mathrm{eV})$ in the range of $12-22 \mathrm{eV}$ depend on s-sigma(C2s-C2s), s-sigma(C2s-Si3s), and psigma(Si3s-Si3p) bonding orbitals, respectively. For PDHS, the spectra between 11.5 and $22 \mathrm{eV}$ show characteristic double peaks (at around 19.5 and $14.0 \mathrm{eV}$ ) which depend on the s-sigma $(\mathrm{C} 2 \mathrm{~s}-\mathrm{C} 2 \mathrm{~s})$ and p-sigma (C2s-C2p) bonding orbitals of the $n$-hexyl pendant groups, respectively. We showed the orbital characters of PDMS, PMPS, and PDHS polymers in Tables IIIV. WD was underestimated as 3.5 and $3.0 \mathrm{eV}$ for (PDMS, PMPS) and PDHS polymers, respectively.

PMPSM and PDPSM Polymers. Simulated spectra in
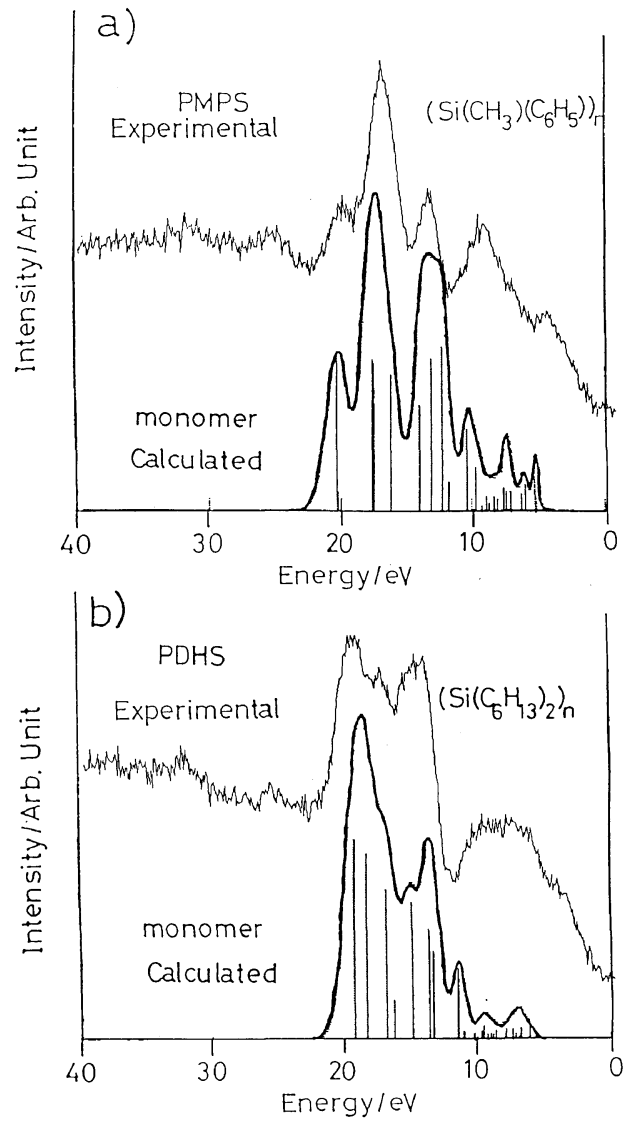

Figure 2. a) Valence XPS of PMPS with the simulated spectra of the model monomer using deMon. b) Valence XPS of PDHS with the simulated spectra of the monomer model molecule using deMon.

Figures $3 \mathrm{a}$ and $3 \mathrm{~b}$ show considerably good agreement with those observed. In both figures, the intense peak at around $17.0 \mathrm{eV}$ was due to s-sigma(C2s-C2s) and s-sigma $(\mathrm{C} 2 \mathrm{~s}-\mathrm{Si} 3 \mathrm{~s})$ bonds of the pendant phenyl group and main chain $-\mathrm{Si}-\mathrm{C}$. The peaks (at around 21.0 and $14.0 \mathrm{eV}$ ) on both sides of the intense signal result from s-sigma $(\mathrm{C} 2 \mathrm{~s}-\mathrm{C} 2 \mathrm{~s})$ and $\mathrm{p}$-sigma $(\mathrm{C} 2 \mathrm{~s}-\mathrm{C} 2 \mathrm{p})$ bonding orbitals of the pendant phenyl, respectively. The spectrum at $10.5 \mathrm{eV}$ results from the $\mathrm{p}$-sigma $(\mathrm{Si} 3 \mathrm{~s}-\mathrm{C} 2 \mathrm{p})$ bonds of the main chain. We showed the main photoionization cross sections of the atomic orbitals, orbital nature, and functional groups for each spectrum of PMPSM in Table $\mathrm{V}$ (similar table of PDPSM was omitted). WD was also underestimated as $3.5 \mathrm{eV}$ for the polymers.

PDMSO and PMPSO Polymers. For PDMSO, and PMPSO (Figures $4 \mathrm{a}$ and $4 \mathrm{~b}$ ), the simulated spectra were in pretty good accordance with the observed ones. In the figures, the intense peak (at around $26 \mathrm{eV}$ ) is due to $\mathrm{s}$, $\mathrm{p}$-sigma $(\mathrm{O} 2 \mathrm{~s}-\mathrm{Si} 3 \mathrm{~s}, 3 \mathrm{p})$ bonds of the main chain, respectively. We showed the orbital characters of PMPSO in Table VI (similar table for PDMSO was omitted). The $W D$ was estimated as $3.0 \mathrm{eV}$ for the models of PDMSO and PPMPSO polymers, respectively.

For the simulated spectra using model molecules, although obtained in the slightly contractive spectral range in Figures 1, 4a, and $4 \mathrm{~b}$, the calculated spectra appeared to show good agreement with the observed ones, when we used an approximate linewidth of $0.10 I_{\mathrm{k}}$. The contractive spectra are able to be improved by the calculations using the rDI model separately in the inner 
Table II. Observed peaks, VIP, main AO PICS, orbital nature, and functional group for valence XPS of PDMS $[($ Shift between observed and calculated VIPs $)=3.5 \mathrm{eV}]$

\begin{tabular}{|c|c|c|c|c|}
\hline Peak/eV & $\mathrm{VIP} / \mathrm{eV}$ & Main AO PICS & Orbital nature $^{\mathrm{b}}$ & Functional group \\
\hline $\begin{array}{c}17.0 \\
(13.5-21.0)^{\mathrm{a}}\end{array}$ & $\begin{array}{l}\{20.7 ; 19.8 ; 19.6 \\
19.0 ; 18.9 ; 18.9\}\end{array}$ & $\begin{array}{c}\mathrm{C} 2 \mathrm{~s}(0.7), \mathrm{Si} 3 \mathrm{~s}(0.3) \\
\mathrm{C} 2 \mathrm{~s}\end{array}$ & $\begin{array}{c}\mathrm{s} \sigma(\mathrm{C} 2 \mathrm{~s}-\mathrm{Si} 3 \mathrm{~s})-\mathrm{B} \\
\mathrm{s} \sigma(\mathrm{C} 2 \mathrm{~s})\end{array}$ & $\begin{array}{l}\mathrm{Si}-\mathrm{C} \\
-\mathrm{CH}_{3}\end{array}$ \\
\hline $\begin{array}{c}10.5 \\
(10.0-12.5)^{\mathrm{a}}\end{array}$ & $15.3 ; 14.2 ; 13.0$ & $\operatorname{Si} 3 s(0.9), C 2 s, \operatorname{Si} 3 p$ & $\mathrm{p} \sigma(\mathrm{Si} 3 \mathrm{~s}-\mathrm{Si} 3 \mathrm{p})-\mathrm{B}$ & $\mathrm{Si}-\mathrm{Si}$ \\
\hline $\begin{array}{c}9.0 \\
(6.5-10.0)^{\mathrm{a}}\end{array}$ & $\begin{array}{c}11.86-12.63 \\
\text { many adjacent levels } \\
11.43-11.79\end{array}$ & $\begin{array}{l}\mathrm{C} 2 \mathrm{p}, \mathrm{Si} 3 \mathrm{~s}, \mathrm{Si} 3 \mathrm{p} \\
\mathrm{C} 2 \mathrm{p}, \mathrm{Si} 3 \mathrm{p}\end{array}$ & $\begin{array}{c}\mathrm{p} \sigma(\mathrm{C} 2 \mathrm{p}-\mathrm{Si} 3 \mathrm{~s}, \mathrm{Si} 3 \mathrm{p})-\mathrm{B} \\
\mathrm{p} \sigma(\mathrm{C} 2 \mathrm{p}-\mathrm{Si} 3 \mathrm{p})-\mathrm{B}\end{array}$ & $\begin{array}{l}-\mathrm{C}-\mathrm{Si} \\
-\mathrm{C}-\mathrm{Si}\end{array}$ \\
\hline $\begin{array}{c}4.5 \\
(1.5-6.5)^{\mathrm{a}}\end{array}$ & $\begin{array}{l}9.47-10.14 \\
8.7 ; 8.1\end{array}$ & $\begin{array}{l}\mathrm{Si} 3 \mathrm{p}(0.7), C 2 \mathrm{~s}, \mathrm{C} 2 \mathrm{p} \\
\mathrm{Si} 3 \mathrm{p}(0.7), \mathrm{Si} 3 \mathrm{~s}\end{array}$ & $\begin{array}{c}\mathrm{p} \sigma(\mathrm{Si} 3 \mathrm{p}-\mathrm{C} 2 \mathrm{~s}, \mathrm{C} 2 \mathrm{p})-\mathrm{B} \\
\mathrm{p} \sigma(\mathrm{Si} 3 \mathrm{p}-\mathrm{Si} 3 \mathrm{~s})-\mathrm{B}\end{array}$ & $\begin{array}{l}\mathrm{Si}-\mathrm{C} \\
\mathrm{Si}-\end{array}$ \\
\hline
\end{tabular}

${ }^{a}$ Peak range. ${ }^{b} \mathrm{~B}$, bonding. (Si3s-C2s, C2p) means (Si3s-C2s) and (Si3s-C2p).

Table III. Observed peaks, VIP, main AO PICS, orbital nature, and functional group for valence XPS of PMPS $[($ Shift between observed and calculated VIPs $)=3.5 \mathrm{eV}]$

\begin{tabular}{|c|c|c|c|c|}
\hline Peak/eV & $\mathrm{VIP} / \mathrm{eV}$ & Main AO PICS & Orbital nature ${ }^{\mathrm{b}}$ & Functional group \\
\hline $\begin{array}{c}19.5 \\
(18.5-22.0)^{\mathrm{a}}\end{array}$ & 23.71 & $\mathrm{C} 2 \mathrm{~s}$ & $\mathrm{~s} \sigma(\mathrm{C} 2 \mathrm{~s}-\mathrm{C} 2 \mathrm{~s})-\mathrm{B}$ & $-\mathrm{C}-\mathrm{C}($ phenyl $)$ \\
\hline $\begin{array}{c}17.0 \\
(14.5-18.5)^{\mathrm{a}}\end{array}$ & $\{21.09 ; 19.65 ; 20.98\}$ & $\begin{array}{c}\mathrm{C} 2 \mathrm{~s}(0.8), \mathrm{Si} 3 \mathrm{~s}(0.2) \\
\mathrm{C} 2 \mathrm{~s}\end{array}$ & $\begin{array}{l}\mathrm{s} \sigma(\mathrm{C} 2 \mathrm{~s}-\mathrm{Si} 3 \mathrm{~s})-\mathrm{B} \\
\mathrm{s} \sigma(\mathrm{C} 2 \mathrm{~s})\end{array}$ & $\begin{array}{c}\mathrm{Si}-\mathrm{C} \\
-\mathrm{C}-\mathrm{C}(\text { phenyl }),-\mathrm{CH}_{3}\end{array}$ \\
\hline $\begin{array}{c}13.0 \\
(12.0-14.5)^{\mathrm{a}}\end{array}$ & $\begin{array}{c}16.6 ; 15.7 ; 15.3 \\
17.45 ; 17.46\end{array}$ & $\begin{array}{l}\mathrm{Si} 3 \mathrm{~s}(0.9), \mathrm{C} 2 \mathrm{~s}, \mathrm{Si} 3 \mathrm{p} \\
\mathrm{C} 2 \mathrm{~s}(0.8), \mathrm{Si} 3 \mathrm{~s}, \mathrm{Si} 3 \mathrm{p}\end{array}$ & $\begin{array}{l}\mathrm{p} \sigma(\mathrm{Si} 3 \mathrm{~s}-\mathrm{Si} 3 \mathrm{p})-\mathrm{B} \\
\mathrm{p} \sigma(\mathrm{C} 2 \mathrm{~s}-\mathrm{C} 2 \mathrm{p})-\mathrm{B}\end{array}$ & $\begin{array}{c}\mathrm{Si}-\mathrm{Si} \\
\mathrm{C}-\mathrm{C}(\text { phenyl })\end{array}$ \\
\hline $\begin{array}{c}9.5 \\
(8.0-11.5)^{\mathrm{a}}\end{array}$ & $\begin{array}{c}13.9 ; 13.5 ; 13.2 \\
\text { many adjacent levels } \\
11.56-12.77\end{array}$ & $\begin{array}{c}\mathrm{Si} 3 \mathrm{~s}, \mathrm{C} 2 \mathrm{~s}, \mathrm{C} 2 \mathrm{p}, \mathrm{Si} 3 \mathrm{p} \\
\mathrm{C} 2 \mathrm{p}, \mathrm{Si} 3 \mathrm{p}, \mathrm{Si} 3 \mathrm{~s}\end{array}$ & $\begin{array}{l}\mathrm{p} \sigma(\mathrm{C} 2 \mathrm{p}-\mathrm{Si} 3 \mathrm{~s}, \mathrm{C} 2 \mathrm{~s})-\mathrm{B} \\
\mathrm{p} \pi(\mathrm{C} 2 \mathrm{p}-\mathrm{C} 2 \mathrm{p}, \mathrm{Si} 3 \mathrm{p})-\mathrm{B}\end{array}$ & $\begin{array}{c}-\mathrm{C}-\mathrm{C}(\text { phenyl }),-\mathrm{C}-\mathrm{Si} \\
-\mathrm{C}-\mathrm{C}(\text { phenyl })\end{array}$ \\
\hline $\begin{array}{c}7.0 \\
(6.0-8.0)^{\mathrm{a}}\end{array}$ & $10.63-11.13$ & $\operatorname{Si} 3 p(0.9), C 2 p$ & $\mathrm{p} \pi(\mathrm{Si} 3 \mathrm{p}-\mathrm{Si} 3 \mathrm{p})-\mathrm{B}$ & $\mathrm{Si}-\mathrm{Si}$ \\
\hline $\begin{array}{c}4.5 \\
(1.5-6.0)^{\mathrm{a}}\end{array}$ & $8.63-9.88$ & $\operatorname{Si} 3 p(0.7), C 2 p$ & $\mathrm{p} \pi(\mathrm{Si} 3 \mathrm{p}-\mathrm{C} 2 \mathrm{p})-\mathrm{B}$ & $-\mathrm{C}-\mathrm{C}$ (phenyl), $\mathrm{Si}-\mathrm{C}$ \\
\hline
\end{tabular}

${ }^{\mathrm{a}}$ Peak range. ${ }^{\mathrm{b}} \mathrm{B}$, bonding. (C2p-Si3s, C2s) means (C2p-Si3s) and (C2p-C2s).

Table IV. Observed peaks, VIP, main AO PICS, orbital nature, and functional group for valence XPS of PDHS $[($ Shift between observed and calculated VIPs $)=3.0 \mathrm{eV}]$

\begin{tabular}{|c|c|c|c|c|}
\hline Peak/eV & $\mathrm{VIP} / \mathrm{eV}$ & Main AO PICS & Orbital nature ${ }^{\mathrm{b}}$ & Functional group \\
\hline $\begin{array}{c}19.5 \\
(18.0-22.0)^{\mathrm{a}}\end{array}$ & $22.34 ; 21.38$ & $\mathrm{C} 2 \mathrm{~s}$ & $\mathrm{~s} \sigma(\mathrm{C} 2 \mathrm{~s}-\mathrm{C} 2 \mathrm{~s})-\mathrm{B}$ & $-\mathrm{C}-\mathrm{C}$ \\
\hline $\begin{array}{c}17.0 \\
(16.0-18.0)^{\mathrm{a}}\end{array}$ & $19.96 ; 19.33$ & $\operatorname{Si} 3 s(0.5), C 2 s(0.5)$ & $\mathrm{s} \sigma(\mathrm{Si} 3 \mathrm{~s}-\mathrm{C} 2 \mathrm{~s})-\mathrm{B}$ & $\mathrm{Si}-\mathrm{C}$ \\
\hline $\begin{array}{c}14.0 \\
(11.5-16.0)^{\mathrm{a}}\end{array}$ & $18.0 ; 16.7 ; 16.4$ & $\mathrm{C} 2 \mathrm{~s}(0.9), \mathrm{Si} 3 \mathrm{~s}, \mathrm{C} 2 \mathrm{p}$ & $\mathrm{p} \sigma(\mathrm{C} 2 \mathrm{~s}-\mathrm{C} 2 \mathrm{p})-\mathrm{B}$ & $-\mathrm{C}-\mathrm{C}$ \\
\hline $\begin{array}{l}10.5 \\
(9.5-11.0)^{\mathrm{a}}\end{array}$ & $\begin{array}{c}14.58 \\
14.11 ; 13.30\end{array}$ & $\begin{array}{l}\mathrm{Si} 3 \mathrm{~s}(0.9), \mathrm{C} 2 \mathrm{p}, \mathrm{Si} 3 \mathrm{p} \\
\quad \mathrm{C} 2 \mathrm{p}, \mathrm{Si} 3 \mathrm{~s}, \mathrm{Si} 3 \mathrm{p}\end{array}$ & $\begin{array}{c}\mathrm{p} \sigma(\mathrm{Si} 3 \mathrm{~s}-\mathrm{C} 2 \mathrm{p})-\mathrm{B} \\
\mathrm{p} \sigma(\mathrm{C} 2 \mathrm{p}-\mathrm{Si3s}, 3 \mathrm{p})\end{array}$ & $\begin{array}{l}\mathrm{Si}-\mathrm{C} \\
-\mathrm{C}-\mathrm{Si}\end{array}$ \\
\hline $\begin{array}{c}8.0 \\
(6.0-9.5)^{\mathrm{a}}\end{array}$ & $11.60-12.74$ & $\mathrm{C} 2 \mathrm{p}, \mathrm{Si} 3 \mathrm{p}, \mathrm{C} 2 \mathrm{~s}$ & $\mathrm{p} \sigma(\mathrm{C} 2 \mathrm{p}-\mathrm{Si} 3 \mathrm{p}, \mathrm{C} 2 \mathrm{~s})-\mathrm{B}$ & $-\mathrm{C}-\mathrm{Si},-\mathrm{C}-\mathrm{C}$ \\
\hline $\begin{array}{c}4.5 \\
(2.0-6.0)^{\mathrm{a}}\end{array}$ & $\begin{array}{c}9.99-10.99 \\
\text { many adjacent levels } \\
9.9 ; 9.8 ; 9.3\end{array}$ & $\begin{array}{l}\mathrm{C} 2 \mathrm{p}(0.6), \mathrm{Si} 3 \mathrm{p} \\
\mathrm{Si} 3 \mathrm{p}(0.8), \mathrm{C} 2 \mathrm{p}\end{array}$ & $\mathrm{p} \pi(\mathrm{C} 2 \mathrm{p}-\mathrm{Si} 3 \mathrm{p})-\mathrm{B}$ & $-\mathrm{C}-\mathrm{C},-\mathrm{C}-\mathrm{Si}$ \\
\hline
\end{tabular}

${ }^{\text {a }}$ Peak range. ${ }^{b} \mathrm{~B}$, bonding. (C2p-Si3s, 3p) means (C2p-Si3s) and (C2p-Si3p). 

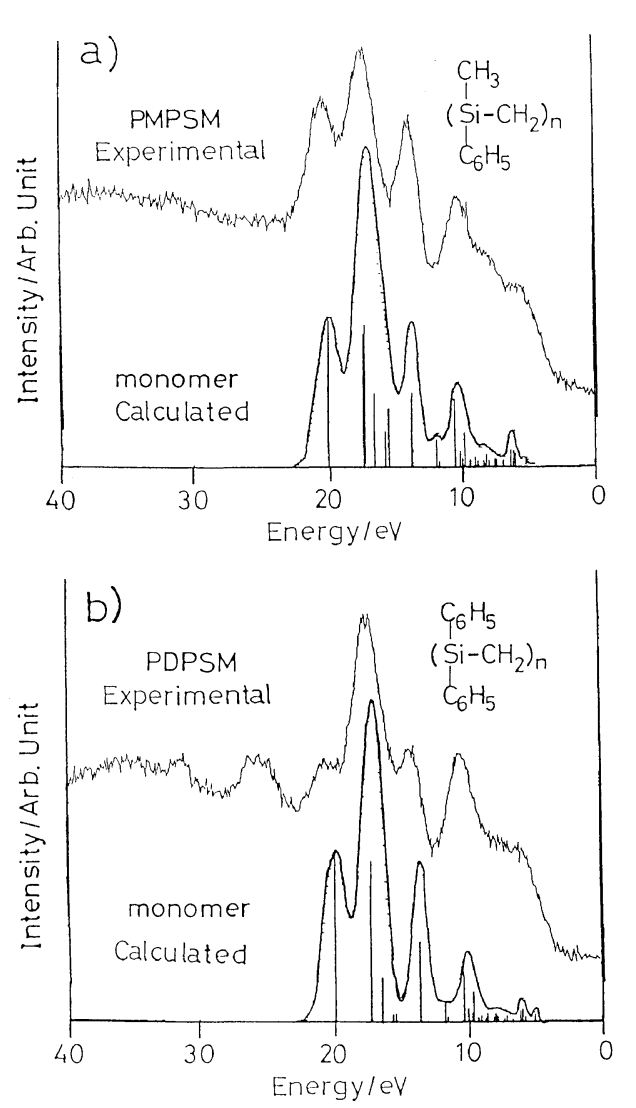

Figure 3. a) Valence XPS of PMPSM with the simulated spectra of the model monomer using deMon. b) Valence XPS of PDPSM with the simulated spectra of the monomer model molecule using deMon.
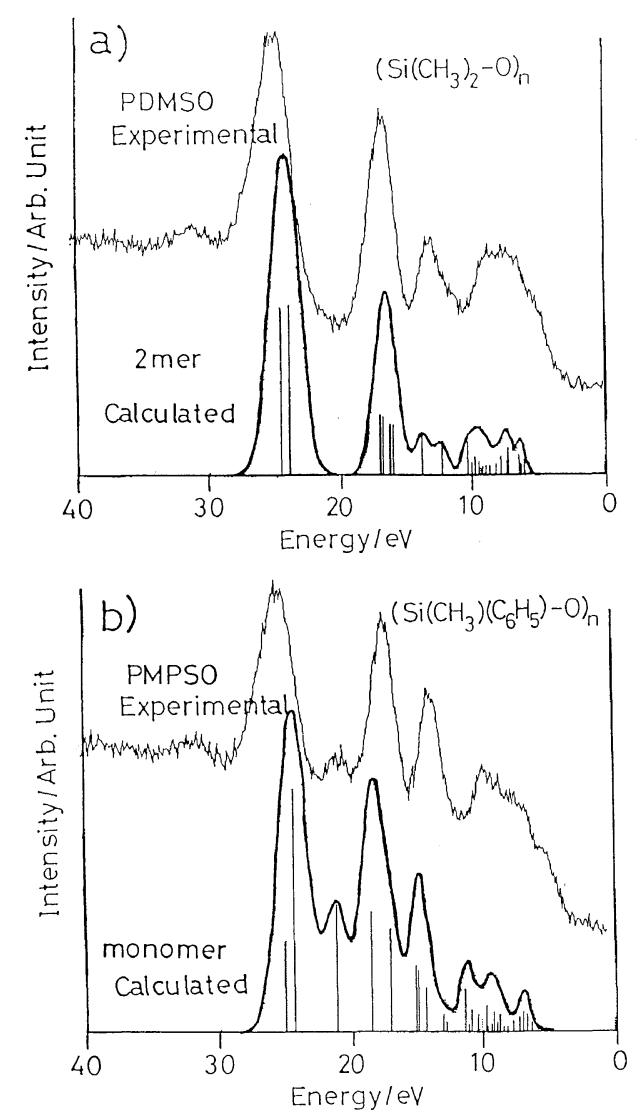

Figure 4. a) Valence XPS of PDMSO with the simulated spectra of the model dimer using deMon. b) Valence XPS of PMPSO with the simulated spectra of the monomer model molecule using deMon.

Table V. Observed peaks, VIP, main AO PICS, orbital nature, and functional group for valence XPS of PMPSM $[($ Shift between observed and calculated VIPs $)=3.5 \mathrm{eV}]$

\begin{tabular}{|c|c|c|c|c|}
\hline Peak/eV & $\mathrm{VIP} / \mathrm{eV}$ & Main AO PICS & Orbital nature ${ }^{\mathrm{b}}$ & Functional group \\
\hline $\begin{array}{c}21.0 \\
(19.5-23.5)^{\mathrm{a}}\end{array}$ & 23.51 & $\mathrm{C} 2 \mathrm{~s}$ & $\mathrm{~s} \sigma(\mathrm{C} 2 \mathrm{~s}-\mathrm{C} 2 \mathrm{~s})-\mathrm{B}$ & $-\mathrm{C}-\mathrm{C}($ phenyl $)$ \\
\hline $\begin{array}{c}17.0 \\
(15.0-19.0)^{\mathrm{a}}\end{array}$ & $18.94-20.97$ & $\mathrm{C} 2 \mathrm{~s}(0.9), \mathrm{Si} 3 \mathrm{~s}$ & $\mathrm{~s} \sigma(\mathrm{C} 2 \mathrm{~s}-\mathrm{C} 2 \mathrm{~s}, \mathrm{Si} 3 \mathrm{~s})-\mathrm{B}$ & $-\mathrm{C}-\mathrm{C}$ (phenyl), $-\mathrm{C}-\mathrm{Si}$ \\
\hline $\begin{array}{c}14.0 \\
(12.0-15.0)^{\mathrm{a}}\end{array}$ & $17.19 ; 17.16$ & $\mathrm{C} 2 \mathrm{~s}(0.9), \mathrm{C} 2 \mathrm{p}$ & $\mathrm{p} \sigma(\mathrm{C} 2 \mathrm{~s}-\mathrm{C} 2 \mathrm{p})-\mathrm{B}$ & $-\mathrm{C}-\mathrm{C}($ phenyl $)$ \\
\hline $\begin{array}{c}10.5 \\
(9.0-12.0)^{\mathrm{a}}\end{array}$ & $\begin{array}{l}15.2 ; 13.9 ; 13.2 \\
15.10 ; 13.35\end{array}$ & $\begin{array}{c}\mathrm{Si} 3 \mathrm{~s}, \mathrm{C} 2 \mathrm{~s}, \mathrm{C} 2 \mathrm{p} \\
\mathrm{C} 2 \mathrm{p}\end{array}$ & $\begin{array}{c}\mathrm{p} \sigma(\mathrm{C} 2 \mathrm{p}-\mathrm{Si} 3 \mathrm{~s}, \mathrm{C} 2 \mathrm{~s})-\mathrm{B} \\
\mathrm{p} \pi(\mathrm{C} 2 \mathrm{p}-\mathrm{C} 2 \mathrm{p})-\mathrm{B}\end{array}$ & $\begin{array}{c}\text {-C-Si, }-\mathrm{C}(\text { phenyl }) \\
-\mathrm{C}-\mathrm{C} \text { (phenyl) }\end{array}$ \\
\hline $\begin{array}{c}8.5 \\
(7.0-9.0)^{\mathrm{a}}\end{array}$ & $11.72-12.80$ & $\mathrm{C} 2 \mathrm{p}, \mathrm{Si} 3 \mathrm{p}$ & $\mathrm{p} \pi(\mathrm{C} 2 \mathrm{p}-\mathrm{C} 2 \mathrm{p}, \mathrm{Si} 3 \mathrm{p})-\mathrm{B}$ & $-\mathrm{C}-\mathrm{C}($ phenyl), $\mathrm{C}-\mathrm{Si}$ \\
\hline \multirow[t]{2}{*}{$\begin{array}{c}6.0 \\
(3.0-7.0)^{\mathrm{a}}\end{array}$} & $\begin{array}{c}10.17-11.57 \\
\text { many adjacent levels }\end{array}$ & $\mathrm{C} 2 \mathrm{p}(0.6), \mathrm{Si} 3 \mathrm{p}$ & $\mathrm{p} \pi(\mathrm{C} 2 \mathrm{p}-\mathrm{C} 2 \mathrm{p}, \mathrm{Si} 3 \mathrm{p})-\mathrm{B}$ & $-\mathrm{C}-\mathrm{C}($ phenyl $), \mathrm{Si}-\mathrm{C}$ \\
\hline & $8.52-9.65$ & $\operatorname{Si} 3 p(0.7), C 2 p$ & $\mathrm{p} \pi(\mathrm{Si} 3 \mathrm{p}, \mathrm{C} 2 \mathrm{p}-\mathrm{C} 2 \mathrm{p})-\mathrm{B}$ & $\mathrm{Si}-\mathrm{C}-, \mathrm{C}-\mathrm{C}($ phenyl $)$ \\
\hline
\end{tabular}

${ }^{a}$ Peak range. ${ }^{b} \mathrm{~B}$, bonding. (C2p-Si3s, C2s) means (C2p-Si3s) and (C2p-C2s).

valence sigma-bonding and the remaining outer valence regions.

It is very interesting that we can observe the characteristic spectra due to the photoionization cross section (PICS) of any contributing atomic orbitals of the constituent elements of the functional groups. For these seven polymers, we clarified the orbital nature of the finger-print spectra which were characterized from the constituent elements $(\mathrm{C}, \mathrm{O}$, and $\mathrm{Si})$ in the range of
$5-30 \mathrm{eV}$.

\section{CEBEs of Seven Silicon-Based Polymers}

The computed CEBEs of seven polymers (PDMS, PMPS, PDHS, PMPSM, PDPSM, PDMSO, and PMPSO) using uGTS model are considerably in good accordance with observed values, as shown in Table VII. In the table, the calculated CEBEs of $\mathrm{H}\left(\mathrm{Si}\left(\mathrm{CH}_{3}\right)_{2}\right)_{3} \mathrm{H}$ and $\mathrm{H}\left(\mathrm{Si}\left(\mathrm{CH}_{3}\right)_{2} \mathrm{O}\right)_{2} \mathrm{H}$ agree well with the experimental 
Table VI. Observed peaks, VIP, main AO PICS, orbital nature, and the functional group for valence XPS of PMPSO $[($ Shift between observed and calculated VIPs $)=3.0 \mathrm{eV}]$

\begin{tabular}{|c|c|c|c|c|}
\hline Peak/eV & $\mathrm{VIP} / \mathrm{eV}$ & Main AO PICS & Orbital nature $^{b}$ & Functional group \\
\hline $\begin{array}{c}26.0 \\
(23-30)^{\mathrm{a}}\end{array}$ & $27.47 ; 26.83$ & $\mathrm{O} 2 \mathrm{~s}$ & $\mathrm{~s} \sigma, \mathrm{p} \sigma(\mathrm{O} 2 \mathrm{~s}-\mathrm{Si} 3 \mathrm{~s}, \mathrm{Si} 3 \mathrm{p})-\mathrm{B}$ & $-\mathrm{O}-\mathrm{Si}$ \\
\hline $\begin{array}{c}21.0 \\
(20-22)^{\mathrm{a}}\end{array}$ & 26.83 & $\mathrm{C} 2 \mathrm{~s}$ & $\mathrm{~s} \sigma(\mathrm{C} 2 \mathrm{~s}-\mathrm{C} 2 \mathrm{~s})-\mathrm{B}$ & C-C(phenyl) \\
\hline $\begin{array}{c}17.0 \\
(15.5-20)^{\mathrm{a}}\end{array}$ & $\begin{array}{c}21.03 ; 20.95 \\
19.52\end{array}$ & $\begin{array}{c}\mathrm{C} 2 \mathrm{~s} \\
\mathrm{C} 2 \mathrm{~s}(0.8), \mathrm{Si} 3 \mathrm{~s}\end{array}$ & $\begin{array}{l}\mathrm{s} \sigma(\mathrm{C} 2 \mathrm{~s}-\mathrm{C} 2 \mathrm{~s})-\mathrm{B} \\
\mathrm{s} \sigma(\mathrm{C} 2 \mathrm{~s}-\mathrm{Si} 3 \mathrm{~s})-\mathrm{B}\end{array}$ & $\begin{array}{l}-\mathrm{C}-\mathrm{C}(\text { phenyl }) \\
\mathrm{C}(\text { methyl) }-\mathrm{Si}\end{array}$ \\
\hline $\begin{array}{c}14.0 \\
(11.5-15.5)^{\mathrm{a}}\end{array}$ & $\begin{array}{c}17.5 ; 17.4 ; 16.9 \\
15.48 ; 15.27\end{array}$ & $\begin{array}{l}\mathrm{C} 2 \mathrm{~s}(0.6), \mathrm{Si} 3 \mathrm{~s}, \mathrm{O} 2 \mathrm{p} \\
\mathrm{Si} 3 \mathrm{~s}, \mathrm{Si} 3 \mathrm{p}, \mathrm{C} 2 \mathrm{~s}, \mathrm{C} 2 \mathrm{p}\end{array}$ & $\begin{array}{l}\mathrm{p} \sigma(\mathrm{C} 2 \mathrm{~s}, \mathrm{Si} 3 \mathrm{~s}-\mathrm{C} 2 \mathrm{p})-\mathrm{B} \\
\mathrm{p} \sigma(\mathrm{C} 2 \mathrm{p}-\mathrm{Si} 3 \mathrm{~s}, \mathrm{C} 2 \mathrm{~s})-\mathrm{B}\end{array}$ & $\begin{array}{l}-\mathrm{C}-\mathrm{C} \text { (phenyl) }-\mathrm{Si} \\
-\mathrm{C}-\mathrm{C} \text { (phenyl) }-\mathrm{Si}\end{array}$ \\
\hline $\begin{array}{c}9.5 \\
(6-11)^{\mathrm{a}}\end{array}$ & $\begin{array}{c}13.8 ; 13.5 ; 13.4 \\
\text { many adjacent levels } \\
10.56-12.84\end{array}$ & $\begin{array}{l}\mathrm{C} 2 \mathrm{~s}, \mathrm{Si} 3 \mathrm{~s}, \mathrm{Si} 3 \mathrm{p}, \mathrm{O} 2 \mathrm{p} \\
\mathrm{O} 2 \mathrm{p}, \mathrm{Si} 3 \mathrm{p}, \mathrm{Si} 3 \mathrm{~s}, \mathrm{C} 2 \mathrm{p}\end{array}$ & $\begin{array}{c}\mathrm{p} \sigma(\mathrm{C} 2 \mathrm{p}-\mathrm{C} 2 \mathrm{~s}, \mathrm{Si} 3 \mathrm{~s}, \mathrm{p})-\mathrm{B} \\
\mathrm{p} \pi(\mathrm{C} 2 \mathrm{p}-\mathrm{C} 2 \mathrm{p}, \mathrm{Si} 3 \mathrm{p})-\mathrm{B}\end{array}$ & $\begin{array}{l}-\mathrm{C}-\mathrm{C}(\text { phenyl })-\mathrm{Si} \\
-\mathrm{C}-\mathrm{C}(\text { phenyl })-\mathrm{Si}\end{array}$ \\
\hline $\begin{array}{c}5.0 \\
(3-6)^{\mathrm{a}}\end{array}$ & $\begin{array}{c}9.6 ; 9.4 ; 9.1 \\
10.1 ; 8.8 ; 8.7\end{array}$ & $\begin{array}{l}\mathrm{O} 2 p, \mathrm{Si} 3 \mathrm{p} \\
\mathrm{C} 2 \mathrm{p}, \mathrm{Si} 3 \mathrm{p}\end{array}$ & $\begin{array}{c}\mathrm{p} \pi(\text { lone-pair })-\mathrm{NB} \\
\mathrm{p} \pi(\mathrm{C} 2 \mathrm{p}-\mathrm{C} 2 \mathrm{p}, \mathrm{Si} 3 \mathrm{p})-\mathrm{B}\end{array}$ & $\begin{array}{c}-\mathrm{O}- \\
-\mathrm{C}-\mathrm{C}(\mathrm{phenyl})-\mathrm{Si}\end{array}$ \\
\hline
\end{tabular}

${ }^{a}$ Peak range. ${ }^{b} \mathrm{~B}$ and NB, bonding and nonbonding, respectively. (C2p-C2p, Si3p) means (C2p-C2s) and (C2p-Si3p), and so on.

Table VII. Core-electron binding energies of Si-containing polymers and of the model molecules Calculations were done with uGTS model from deMon density-functional program using the model molecules (in eV).

\begin{tabular}{|c|c|c|c|c|c|c|}
\hline \multirow{2}{*}{ Polymers } & \multirow{2}{*}{ Observed } & & \multicolumn{4}{|c|}{ Model molecules } \\
\hline & & & Calculated & $W D$ & Experiment $^{\mathrm{a}}$ & $W D$ \\
\hline $\begin{array}{l}\text { PDMS } \\
\left(\mathrm{Si}\left(\mathrm{CH}_{3}\right)_{2}\right)_{n} \\
\quad \mathrm{CEBE}(\mathrm{C} 1 \mathrm{~s})\left[-\mathrm{CH}_{3}\right] \\
\quad \mathrm{CEBE}(\mathrm{Si} 2 \mathrm{p})\end{array}$ & $\begin{array}{r}283.5 \\
98.1\end{array}$ & $\mathrm{H}-\left(\mathrm{Si}\left(\mathrm{CH}_{3}\right)_{2}\right)_{3}-\mathrm{H}$ & $\begin{array}{l}290.30 \\
106.21\end{array}$ & $\begin{array}{l}6.8 \\
8.1\end{array}$ & $\begin{array}{l}290.14^{\left(\mathrm{CH}_{3}\right.} \\
106.71\end{array}$ & $\begin{array}{l}6.6 \\
8.6\end{array}$ \\
\hline $\begin{array}{l}\text { PMPS } \\
\left(\mathrm{Si} \phi\left(\mathrm{CH}_{3}\right)\right)_{n} \\
\quad \mathrm{CEBE}(\mathrm{Cl}) \\
\quad \mathrm{CEBE}(\mathrm{Si} 2 \mathrm{p})\end{array}$ & $\begin{array}{r}284.0 \\
98.3\end{array}$ & $\begin{array}{c}\mathrm{H}-\left(\mathrm{Si \phi}\left(\mathrm{CH}_{3}\right)\right) \mathrm{H} \\
{\left[-\underline{\mathrm{C}}_{3}\right]} \\
{\left[-\underline{\mathrm{C}}_{6} \mathrm{H}_{5}\right]}\end{array}$ & $\begin{array}{l}290.43 \\
290.47 \\
106.82\end{array}$ & $\begin{array}{l}6.4 \\
6.5 \\
8.5\end{array}$ & & \\
\hline $\begin{array}{l}\text { PDHS } \\
\left(\mathrm{Si}\left(\mathrm{C}_{6} \mathrm{H}_{13}\right)_{2}\right)_{n} \\
\text { CEBE }(\mathrm{C} 1 \mathrm{~s}) \\
\text { CEBE }(\mathrm{Si} 2 \mathrm{p})\end{array}$ & $\begin{array}{r}284.5 \\
98.4\end{array}$ & $\begin{array}{c}\mathrm{H}-\left(\mathrm{Si}\left(\mathrm{CH}_{3}\right)\left(\mathrm{C}_{6} \mathrm{H}_{13}\right)\right)-\mathrm{H} \\
{\left[\mathrm{Si}-\mathrm{CH}_{2}-\mathrm{CH}_{2}^{-}\right]}\end{array}$ & $\begin{array}{l}290.65 \\
106.34\end{array}$ & $\begin{array}{l}6.2 \\
7.9\end{array}$ & & \\
\hline $\begin{array}{l}\text { PMPSM } \\
\left(\mathrm{Si} \phi\left(\mathrm{CH}_{3}\right)-\mathrm{CH}_{2}\right)_{n} \\
\quad \mathrm{CEBE}(\mathrm{Cl}) \\
\text { CEBE }(\mathrm{Si} 2 \mathrm{p})\end{array}$ & $\begin{array}{r}283.2 \\
97.6\end{array}$ & $\begin{array}{c}\mathrm{H}-\left(\mathrm{Si} \phi\left(\mathrm{CH}_{3}\right)\right)-\mathrm{H} \\
{\left[-\underline{\mathrm{CH}}_{3}\right]} \\
{\left[-\underline{\mathrm{C}}_{6} \mathrm{H}_{5}\right]}\end{array}$ & $\begin{array}{l}290.43 \\
290.47 \\
106.82\end{array}$ & $\begin{array}{l}7.2 \\
7.3 \\
9.2\end{array}$ & & \\
\hline $\begin{array}{l}\operatorname{PDPSM} \\
\left(\mathrm{Si}(\phi)_{2}-\mathrm{CH}_{2}\right)_{n} \\
\mathrm{CEBE}(\mathrm{C} 1 \mathrm{~s}) \\
\mathrm{CEBE}(\mathrm{Si} 2 \mathrm{p})\end{array}$ & $\begin{array}{r}283.4 \\
97.8\end{array}$ & $\begin{array}{c}\mathrm{H}-\left(\mathrm{Si} \phi\left(\mathrm{CH}_{3}\right)\right)-\mathrm{H} \\
{\left[-\underline{\mathrm{C}}_{6} \mathrm{H}_{5}\right]}\end{array}$ & $\begin{array}{l}290.47 \\
106.82\end{array}$ & $\begin{array}{l}7.1 \\
9.0\end{array}$ & & \\
\hline $\begin{array}{l}\text { PDMSO } \\
\left(\mathrm{Si}\left(\mathrm{CH}_{3}\right)_{2}-\mathrm{O}\right)_{n} \\
\quad \mathrm{CEBE}(\mathrm{O} 1 \mathrm{~s}) \\
\mathrm{CEBE}(\mathrm{Cls})\left[-\mathrm{CH}_{3}\right] \\
\text { CEBE }(\mathrm{Si} 2 \mathrm{p})\end{array}$ & $\begin{array}{l}531.8 \\
284.6 \\
101.0\end{array}$ & $\mathrm{H}-\left(\mathrm{Si}\left(\mathrm{CH}_{3}\right)_{2}-\mathrm{O}\right)_{2}-\mathrm{H}$ & $\begin{array}{l}537.27 \\
290.37 \\
108.00\end{array}$ & $\begin{array}{l}5.5 \\
5.8 \\
7.0\end{array}$ & $\begin{array}{l}\quad\left(\left(\mathrm{CH}_{3}\right)\right. \\
537.32 \\
289.90 \\
106.83\end{array}$ & $\begin{array}{l}-\mathrm{O} \\
5.5 \\
5.3 \\
5.8\end{array}$ \\
\hline $\begin{array}{l}\text { PPMSO } \\
\left(\mathrm{Si} \phi\left(\mathrm{CH}_{3}\right)-\mathrm{O}\right)_{n} \\
\quad \mathrm{CEBE}(\mathrm{O} 1 \mathrm{~s}] \\
\mathrm{CEBE}(\mathrm{Cls})\left[-\mathrm{CH}_{3}\right] \\
\quad \mathrm{CEBE}(\mathrm{Si} 2 \mathrm{p})\end{array}$ & $\begin{array}{l}531.5 \\
284.6 \\
100.8\end{array}$ & $\mathrm{H}-\left(\mathrm{Si} \phi\left(\mathrm{CH}_{3}\right)-\mathrm{O}\right) \mathrm{H}$ & $\begin{array}{l}538.17 \\
290.25 \\
108.10\end{array}$ & $\begin{array}{l}6.7 \\
5.7 \\
7.3\end{array}$ & & \\
\hline
\end{tabular}

${ }^{a}$ Values cited from CEBEs by Drake et al. 
CEBEs of $\left(\mathrm{CH}_{3}\right)_{2} \mathrm{SiH}_{2}$ and $\left(\left(\mathrm{CH}_{3}\right)_{2} \mathrm{SiH}\right)_{2} \mathrm{O}$ in gas, as observed by Drake and co-workers. ${ }^{34}$ Good results were obtained with uGTS model and with a little larger scaled pVTZ basis set than with DZVP basis. The differences between the calculated and observed values reflect the values of reasonable WDs in comparison with those of $3.0-3.5 \mathrm{eV}$, as underestimated from the VIPs. When we take into consideration the long acquisition times of valence-region XPS due to the 20- to 100 -fold weaker intensities and hence the possible $\mathrm{X}$-ray radiation damage, we conclude that $W D$ from CEBEs may very well be the most reliable.

In our previous work, ${ }^{26,35,36}$ we showed that $W D$ for 16 polymers obtained from the differences between the calculated and experimental CEBEs of the C1s were resonable. By considering the results from CEBEs of $\mathrm{C} 1 \mathrm{~s}$, $W D$ of the silicon-based polymers can be classified as; $6.2-6.8 \mathrm{eV}$ for silylene-polymers $\left((-\mathrm{Si}-)_{n}\right), 7.1-7.2 \mathrm{eV}$ for silamethylene-polymers $\left((-\mathrm{Si}-\mathrm{C}-)_{n}\right)$, and $5.7-5.8 \mathrm{eV}$ for siloxythane-polymers $\left((-\mathrm{Si}-\mathrm{O}-)_{n}\right)$, respectively.

\section{CONCLUSIONS}

We calculated the valence XPS and core-electron binding energies of silicon-based polymers by a deMon density functional method using the model oligomers or monomer. We emphasize that the calculated VIPs and CEBEs of polymer models using rDI and uGTS models, respectively, by deMon program showed better agreement with experimental results. The difference between the calculated and observed CEBEs for $\mathrm{C} 1 \mathrm{~s}$ reflected the trend of WD values of the silicon-based polymers.

Acknowledgments. We thank Prof. D. R. Salahub of University of Montreal for the deMon density functional program. We thank the New Energy and Industrial Technology Development Organization (NEDO) for its support. This work was collaborated as a part of the Industrial Science and Technology Frontier program as supported by the NEDO.

\section{REFERENCES}

1. R. J. Miller, in "Silicon Based Polymer Science: A Comprehensive Resource," J. M. Zeigler and F. W. Fearon, Ed., American Chemical Society, Washington, D.C., 1990.

2. S. Yajima, Am. Ceram. Bull., 62, 893 (1983).

3. A. R. Wolff and R. West, Appl. Organomet., 1, 7 (1987).

4. M. Abkowitz and M. Stolka, Philos. Mag. Lett., 58, 239 (1988).

5. F. Kajzar, J. Messier, and C. Rosilio, J. Appl. Phys., 60, 3040
(1986).

6. R. D. Miller, Chem. Rev., 89, 1359 (1989).

7. A-F. de Mahieu, D. Daous, J. Devaux, and M. de Valck, Eur. Polym. J., 28, 685 (1992).

8. A-F. de Mahieu, D. Daous, J. Devaux, M. de Valck, and C Strazielle, Bull. Soc. Chim. Belg., 98, 803 (1989).

9. J. Devaux, D. Daous, A-F. de Mahieu, and C. Strazielle, in "Inorganic and Organometallic Oligomers and Polymers," J. F. Harrod and R. M. Laine, Ed., Kluwer Academic, Dordrecht, 1991.

10. A-F. de Mahieu, J. Devaux, C. Dereppe, G. Baudoux, and J. Delhalle, J. Polym. Sci., Part A, Polym. Chem. Ed., 34, 763 (1996)

11. K. Seki, T. Mori, H. Inokuchi, and K. Murano, Bull. Chem. Soc. Jpn., 61, 351 (1988).

12. K. Endo, Y. Kaneda, M. Aida, and D. P. Chong, J. Phys. Chem. Solids, 66, 1131 (1995).

13. M. Aida, Y. Kaneda, N. Kobayashi, K. Endo, and D. P. Chong, Bull. Chem. Soc. Jpn., 67, 2972 (1994).

14. K. Endo, C. Inoue, Y. Kaneda, M. Aida, N. Kobayashi, and D. P. Chong, Bull. Chem. Soc. Jpn., 68, 528 (1995).

15. L. Asbrink, C. Fridh, and E. Lindholm, Chem. Phys. Lett., 52, 63; QCPE, 12, 398 (1980).

16. L. Asbrink, C. Fridh, and E. Lindholm, Chem. Phys. Lett., 52, 69 (1977).

17. E. Lindholm and L. Asbrink, "Molecular Orbitals and Their Energies, Studied by the Semiempirical HAM Method," Springer-Verlag, Berlin, 1985

18. D. P. Chong, Can. J. Chem., 63, 2007 (1985).

19. J. C. Slater, Advan. Quantum Chem., 6, 1 (1972).

20. A. St-Amant and D. R. Salahub, Chem. Phys. Lett., 169, 387 (1990); A. St-Amant, Ph.D. Thesis, University of Montreal (1991).

21. D. P. Chong, Chem. Phys. Lett., 220, 102 (1994).

22. P. Duffy and D. P. Chong, Org. Mass Spectrom., 28, 321 (1993).

23. D. P. Chong, Chem. Phys. Lett., 232, 486 (1995).

24. D. P. Chong, J. Chem. Phys., 103, 1842 (1995).

25. D. P. Chong, C.-H. Hu, and P. Duffy, Chem. Phys. Lett., 249, 491 (1996).

26. K. Endo, Y. Kaneda, H. Okada, D. P. Chong, and P. Duffy, $J$. Phys. Chem., 100, 19455 (1996).

27. U. Gelius and K. Siegbahn, Faraday Discus. Chem. Soc., 54, 257 (1972); U. Gelius and J. Electron, Spectrosc. Relat. Phenom., 5, 985 (1974).

28. A. R. Williams, R. A. deGroot, and C. B. Sommers, J. Chem Phys., 63, 628 (1975).

29. J. F. Janak, Phys. Rev. A, 18, 7165 (1978)

30. M. J. S. Dewar and E. G. Zoebisch, Theochem., 180, 1 (1988); M. J. S. Dewar, E. G. Zoebisch, E. F. Healy, and J. J. P. Stewart, J. Am. Chem. Soc., 107, 3902 (1985).

31. A. D. Becke, Phys. Rev. A, 38, 3098 (1988).

32. J. P. Perdew, Phys. Rev. B, 33, 8822 (1986).

33. J.-J. Yeh, "Atomic Calculation of Photoionization Cross Section and Asymmetry Parameters," Gordon and Breach Science Publishers, Newark, NJ, 1993.

34. J. E. Drake, C. Riddle, B. Glavincevski, K. Gorzelska, and H. E. Henderson, Can. J. Chem., 55, 2957 (1977); J. E. Drake, C. Riddle, H. E. Henderson, and B. Glavincevski, Can. J. Chem., 55, 2957 (1977).

35. K. Endo, S. Maeda, and M. Aida, Polym. J., 29, 171 (1977).

36. K. Endo, S. Maeda, and Y. Kaneda, Polym. J., 29, 255 (1977). 